\title{
Késő római telep Ordacsehi határában
}

\author{
NÉMETH PÉTER GERGELY
}

Rippl-Rónai Megyei Hatókörü Városi Múzeum

H-7400 Kaposvár, Fő u. 10., e-mail: peter@smmi.hu

\begin{abstract}
NÉmeth, P. G.: Late Roman Settlement near Ordacsehi. Abstract: The sand-pit cc. $2.5 \mathrm{kms}$ southeast of the settlement Ordacsehi has occasionally yielded objects referring to a Late Roman site since 1990. Based on the finds, the site was populated from the last third of the $4^{\text {th }}$ century through the first third of the $5^{\text {th }}$ century. The special feature of the centrally located bone manufacture is that it is not situated in a major settlement or even well inside the province. The full process of the Roman age settlement, where further artefacts made of bone and antler can be found, may increase the significance of the workshop.
\end{abstract}

Keywords: Late Roman Age, settlement, Bone manufacturing workshop

Az Ordacsehi településtöl délkeletre, mintegy 2,5 kmre lévő homokbányában, 1990-től, több ízben kerültek elő leletek. 1990-ben Bárdos Edith római kori kemence és ház maradványait mentette meg (1990/1-2. objektum). ${ }^{1}$ 1991-ben, kora bronzkori telep, kelta telep és temető mellett, egy római gödör került elő (14. objektum). ${ }^{2}$ 1993-ban, bronzkori gödrök mellett, két római kori gödör látott napvilágot (25-26. objektum). ${ }^{3}$ 1996-ban, bronzkori gödrök mellett, újabb két római gödröt sikerült megmenteni (34. és 38. objektum). ${ }^{4}$ 1997-ben Aradi Csilla a bánya falában újabb római gödröt figyelt meg (43. objektum). ${ }^{5}$ 2004-ig összesen 73 objektum került elö, köztük 8 a római kori. 2004-ben, a bánya DNy-i részén újabb római településrészlet került feltárása. 2006-ban, az ÉK-i részen, újabb objektumokat sikerült megmenteni. ${ }^{6}$ A kécsimezői leletek közül a kelta telep és temető leletei kerültek eddig bemutatásra. ${ }^{7}$ A tanulmány a 2004-ig feltárt római objektumokat mutatja be. A korai leletmentésekről összefüggő helyszínrajz nem készült, a római kori telepobjektumok egy kb. $50 \times 100$ méteres területen kerültek elő, nagyjából a bánya közepén. A bányaművelés az objektumokat csaknem teljesen elpusztította. Az objektumok leírásánál a jelenlegi mélységet adjuk meg, az eredeti mélység, a bányaművelés miatt, 50-100 centiméterrel lehetett magasabb.

1 Bárdos Edithnek a publikációs jog átengedését ezúton is köszönöm. 1991-ben az objektumok számozása újrakezdődött, ezért kapta a ház és a kemence az 1990/1-2. számot. A leletek bejelentését Horváth Ivánnak (Balatonboglár. Úttörő u. 5.) ezúton is köszönöm. A leletek leltári száma: R.2000.3.1.-13.1. A rajzokat Ambrus Edit, a fotókat Balla Krisztián készítette, a táblaszerkesztést Nyári Zsolt készítette. Mindnyájuk munkáját ezúton is köszönöm.

2 Németh Péter Gergely leletmentése. Régészeti Füzetek Ser. 1. No. 45. (1993). 20.

3 Honti Szilvia- Költő László-Németh Péter Gergely leletmentése.

4 Honti Szilvia és Németh Péter Gergely leletmentése.

5 Mógáné Aradi Csillának a publikációs jog átengedését ezúton is köszönöm.

6 Régészeti Kutatások Magyarországon 2004, 258-9. és 2006, 251.

7 Németh-K. Zoffmann-Bartosiewicz 2002

\section{0/1. objektum}

Kenyérsütő kemence, szabálytalan alakú hamusgödörrel. A tüzelőtér tapasztása mintegy az égőtér felében maradt meg. A nagyjából kelet-nyugati irányú hamusgödör formája nagyjából ovális, alja, a kemence szájánál tapasztott. A kemence átmérője $110 \mathrm{~cm}$. A hamusgödör $\mathrm{H}: 190 \mathrm{~cm}$. Sz: $120 \mathrm{~cm}$. (V. tábla. 1.)

1. Csontfésú

Háromrészes csontfésü. A középső rész két széle félkör alakú kivágású, a szorítólemezek vésett díszítésűek. 4 felerősítő vasszeg maradt meg. H: 9,5 cm. Sz: 4,9 cm. Ltsz: R.2000.3.1. (I. tábla. 1.)

2. Csontfésü töredéke

A szorítólemez töredéke. Koncentrikus körrel, félkör alakú és párhuzamos díszítéssel. Tör. $\mathrm{H}: 4,7 \mathrm{~cm}$. Tör. Sz: $1 \mathrm{~cm}$. V: $0,9 \mathrm{~cm}$. Ltsz: R.2000.3.2. (I. tábla. 2.)

3. Edény töredékei

Kihajló peremű, bordadíszes edény összeillő töredékei. Erősen kopott besimítással, világosszürke. H: 10,5 cm. Sz: 6 cm. Fv: 0,5 cm. Ltsz: R.2000.3.3. (I. tábla. 6.) 4. Fazék peremtöredékei

Kihajló, profilált peremü, szürke színü, összeillő töredékek. H: $6,5 \mathrm{~cm}$. Sz: $2,5 \mathrm{~cm}$. Fv: $0,5 \mathrm{~cm}$. Ltsz: R.2000.3.4. (I. tábla. 4.)

5. Fazéktöredék

Kihajló, levágott peremü, a vállon fésüsdíszszel, szürke. H: 9,2 cm. Sz: $6 \mathrm{~cm}$. Fv: 0,5 cm. Ltsz: R.2000.3.5. (I. tábla. 13.)

6. Aljtöredék

Jól korongozott, szürke színű, egyenes fenekű aljtöredék. Esetleg az előző edény darabja. $\mathrm{H}: 4,2 \mathrm{~cm}$. Sz: 3,4 cm. Fv: 0,6 cm. Ltsz: R.2000.3.6. (I. tábla. 8.) 7. Fazéktöredék

Kihajló peremű fazék töredékei. Kaviccsal sűrūn soványított, szürke. $\mathrm{H}: 13 \mathrm{~cm}$. Sz: $5,2 \mathrm{~cm}$. Fv: 0,7 cm. Ltsz: R.2000.3.7. (I. tábla. 11.)

8. Aljtöredék

Egyenes fenekű töredék, esetleg az előző edényhez tartozik. H: 4 cm. Sz: 3,2 cm. Ltsz: R.2000.3.7.

9. Fazék peremtöredéke

Kihajló, profilált, sötétszürke színű töredék. $\mathrm{H}: 4,1 \mathrm{~cm}$. Sz: 1,9 cm. Fv: 0,6 cm. Ltsz: R.2000.3.8. (I. tábla. 5.)

10. Fazék peremtöredékei

Kihajló, összeillő, sötétszürke színű töredékek. H: 10,5 cm. SZ: 4,2 cm. Fv: 0,7 cm. Ltsz: R.2000.3.9. (I. tábla. 3.) 11. Fazekak oldaltöredékei

Különböző edények szürke és barna színü, díszítetlen töredékei. Részben az előző edényekhez tartozhatnak. Átlagos Fv: 0,5 cm. Ltsz: R.2000.3.10-11. és 14-15. 


\section{Edény töredékei}

Bordadíszes oldaltöredékek, az egyiken a fül indulása megmaradt. Finoman iszapolt, szürke. $\mathrm{H}: 3,7 \mathrm{~cm}$ Sz: 3,1 cm. Fv: 0,3 cm, ill. H: 5,5 cm. Sz: 4,5 cm. Ltsz: R.2000.3.13. (I. tábla. 7. és 10.)

13. Edénytöredék

Árkolt, barna színű töredék, esetleg fedő töredéke. H: 4,2 cm. Sz: 2,8 cm. Fv: 0,7 cm. Ltsz: R.2000.3.14. 14. Aljtöredék

Kézi korongon készült, szürke és fekete foltos barna színű, egyenetlenül kiégetett. $\mathrm{H}: 4,9 \mathrm{~cm}$. Sz: 4,8 cm. Fv: 0,7 cm. Ltsz: R.2000.3.12. (I. tábla. 9.)

15. Fenőkő töredéke

Trapéz keresztmetszetű, szürke színű töredék. H: $6 \mathrm{~cm}$. Sz: 2,5 cm. Ltsz: R.2000.3.16. (I. tábla. 12.). Anyaga kvarc homokkő, melynek legközelebbi elöfordulása a Káli-medence. ${ }^{8}$

16. Téglatöredék

Vörös színü töredék. H: 9,9 cm. Sz: $5,5 \mathrm{~cm}$. Ltsz: R.2000.3.17.

\section{0/2. objektum}

Nyugat-kelet tájolású ház, téglalap alakú, lekerekített sarkokkal. Fala meredek, alja egyenes. A délnyugati részén sekély (mélysége kb. $5 \mathrm{~cm}$ ), ovális része lehetett a ház belépője. Négy sarkán egy-egy, a keleti (rövidebb) oldal közepén egy, míg az északi falnál, egymás mellett, további két cölöplyuk tartozott hozzá. Alján, középen, egy-egy nagyobb, vörösen átégett rész volt, ezek, esetleg, tüzelőhelyek lehettek. A ház alján, elszórva, több álltacsont feküdt. Az egyik átégett területen számos szövőszéknehezék volt, egy darab hevert másutt, az északi falnál lévő kettős cölöplyuknál. Egy további töredék a ház belépőjénél került elő. $A$ nehezékek feltehetően egyazon szövőszékhez tartoztak. A ház H: $410 \mathrm{~cm}$. Sz: $300 \mathrm{~cm}$. Mé: $50 \mathrm{~cm}$, a K-i falnál $34 \mathrm{~cm}$. A cölöplyukak mélysége: 29, 20, 15, 20, 18, 26 és $44 \mathrm{~cm}$. (V. tábla. 2.) 1. ásónyom:

1. Fazék oldaltöredéke

Erősen átégett, sötétszürke színü töredék. H: 3,4 cm. Sz: 2,6 cm. Fv: 0,5 cm. Ltsz: R.2000.4.1. (II. tábla. 8.)

2. Oldaltöredék

Finoman iszapolt, szürke színü válltöredék. H: 2,5 cm. Sz: 2,9 cm. Fv: 0,5 cm. Ltsz: R.2000.4.2.

3. Kovadarab

Hússzínü töredék. H: $3,9 \mathrm{~cm}$. Sz: $2 \mathrm{~cm}$. Ltsz: R.2000.4.3.

4. Kőtöredék

Megmunkált, szürke színű, meszes homokkő. H: 9,5 cm. Sz: 9,1 cm. Ltsz: R.2000.4.6. (I. tábla. 14.)

5. Kötöredék

Szürke színű, amorf töredék. H: $7,5 \mathrm{~cm}$. Sz: 6,9 cm. Ltsz: R.2000.4.4. Anyaga bazalttufa, valószínüleg - a leletmentéseken előkerült többi bazalttufával együtt - a fonyódi Várhegyből származik.

6. Paticsdarabok

Salakosra átégett, vörös-szürke színü töredékek. $\mathrm{H}:$ 7,4 és 9,5 cm. Sz: 5,8 és 9,9 cm. Ltsz: R.2000.4.6.

8 A lelőhelyről előkerült kőanyag meghatározását Ábrahám Leventének ezúton is köszönöm.

\section{2. ásónyom:}

7. Táltöredék

Kihajló peremű, finoman iszapolt, barna. $\mathrm{H}: 4,2 \mathrm{~cm}$.

Sz: 4,6 cm. Fv: 0,7 cm. Ltsz: R.2000.4.7. (II. tábla. 2.)

8. Fazéktöredék

Kihajló peremü, keményre kiégetett, sötétszürke.

H: 3,9 cm. Sz: 4,6 cm. Fv: 0,5 cm. Ltsz: R.2000.4.8.

(II. tábla. 7.)

9. Oldaltöredékek

Esetleg az előző edény oldaltöredékei. $\mathrm{H}: 3 \mathrm{~cm}$. Sz:

$2,8 \mathrm{~cm}$. Fv: 0,7 cm, ill. H: 3,9 cm. Sz: $2,2 \mathrm{~cm}$. Fv: 0,5 cm. Ltsz: R.2000.4.9.

10. Fazéktöredék

Árkolt oldaltöredék, szürke-barna. H: 9,4 cm. Sz: $4,4 \mathrm{~cm}$. Fv: 0,6 cm. Ltsz: R.2000.4.10. (II. tábla. 4.)

11. Töredékes fenőkő

Négyzet keresztmetszetű, erősen használt, félbetörött. Fekete foltos, szürke színű kvarc homokkő. H: $12,4 \mathrm{~cm}$. Sz: 3,4 cm. M: 1,5 cm. Ltsz: R.2000.4.11. (II. tábla. 5.) Leletek mélységadat nélkül:

12. Fazék aljtöredéke

Összeillő aljtöredékek. Rosszul kiégetett, kavicscsal sürün soványított, barna. Tör. M: $6 \mathrm{~cm}$. Fv: 0,8 cm. Ltsz: R.2000.4.12. (II. tábla. 10.)

13. Fazék aljtöredéke

Összeillő aljtöredékek. Kaviccsal sürün soványított, szürke-barna. Tör. M: $6 \mathrm{~cm}$. Fv: 0,6 cm. Ltsz: R.2000.4.13. (II. tábla. 12).

14. Fazéktöredék

Bordadíszes oldaltöredék, esetleg az előző edény darabja. $\mathrm{H}: 3 \mathrm{~cm}$. Sz: 1,6 cm. Fv: 0,7 cm. Ltsz: R.2000.4.14

15. Fazék aljtöredéke

Esetleg az előző két edénytöredékhez tartozó darab. Tör. M: 2,1 cm. Fv: 0,7 cm. Ltsz: R.2000.4.15.

16. Fazék töredékei

Valószínűleg egy edényhez tartozó alj- és oldaltöredék. Barna, belül fekete. $\mathrm{H}$ : $6,1 \mathrm{~cm}$. Sz: 4,1 cm. Fv: 0,7 cm, ill. Tör. M: 4,5 cm. Ltsz: R.2000.4.16.

17. Fazék válltöredékei

Keményre kiégetett, szürke színű töredékek. $\mathrm{H}: 4,2$ cm. Sz: 3,5 cm. Fv: 0,8 cm. (II. t. 1). A másik töredék H: $6,2 \mathrm{~cm}$. Sz: 4,9 cm. Ltsz: R.2000.4.17.

18. Fazéktöredék

Kézi korongon készült, Seprűs díszes, kaviccsal sürün soványított, szürke. H: $6 \mathrm{~cm}$. Sz: $3,9 \mathrm{~cm}$. Fv: 0,6 cm. Ltsz: R.2000.4.18.

19. Edény oldaltöredéke

Másodlagosan megégett, fekete foltos vörös színű töredék. H: $6 \mathrm{~cm}$. Sz: 5,6 cm. Fv: $1 \mathrm{~cm}$. Ltsz: R.2000.4.19.

20. Kőtöredék

Amorf töredék, szürke színű bazalttufa. $\mathrm{H}: 8,2 \mathrm{~cm}$. Sz: 5,5 cm. Ltsz: R.2000.4.20.

21. Patics

Áglenyomatos töredék, szürke-barna. $\mathrm{H}: 13,5 \mathrm{~cm}$. Sz: 10,5 cm. M: 6 cm. Ltsz: R.2000.4.21.

22. Tegulatöredék

Vörös színü, kopott töredék. H: $8 \mathrm{~cm}$. Sz: 9,2 cm. M: 5,5 cm. Ltsz: R.2000.4.22. 


\section{Téglatöredék}

Vörös színü, kopott, belső oldalán habarcsnyommal. Az egyik tüzelőhelyből került elő. H: $14 \mathrm{~cm} \mathrm{Sz:}$ 11,5 cm. Ltsz: R.2000.4.23.

Az objektum alja:

\section{Szövőszéknehezékek}

Gúla alakúak, rosszul kiégetettek, ezért a barna színủ darabokon szürke vagy fekete foltok láthatók. Felső harmadukban átfúrás van, egy részükön a felerősítő zsinór lenyomata is megmaradt. Ltsz: R.2000.4-24.

Gúla alakú, tetején benyomás, oldalán a szövőszék zsinórjának lenyomata megmaradt. M: $12,3 \mathrm{~cm}$. Sz: $7,3 \mathrm{~cm}$. (II. tábla. 3.).

Gúla alakú, tetején benyomás, oldalán a szövőszék zsinórjának lenyomata megmaradt. M. $12,3 \mathrm{~cm}$. Sz: $7,3 \mathrm{~cm}$. (II tábla. 6.).

Gúla alakú, tetején benyomás, oldalán a szövőszék zsinórjának lenyomata megmaradt. M: 9,8 cm. Sz: 6,1$7,8 \mathrm{~cm}$. (II. tábla. 9.).

Gúla alakú, tetején benyomás. M. 12,5 cm. Sz: 6-7,3 $\mathrm{cm}$. (II. tábla. 11.).

Gúla alakú. M: 13,4 cm. Sz: $8 \mathrm{~cm}$. (II. tábla. 13.)

Gúla alakú nehezékek, aljuk hiányos, az egyik darabon a szövőszék zsinórjának benyomódása megmaradt. M: $10 \mathrm{~cm}$. Sz: 7,5-7,8 cm és M: 10,8 cm. Sz: 6,7-7,8 cm.

Gúla alakúak, tetejükön benyomás. $M: 11,1 \mathrm{~cm}$. Sz: $5,6-8,7 \mathrm{~cm}, \mathrm{M}: 11,3 \mathrm{~cm}$. Sz: 5,8-6,3 cm és $M: 11,8 \mathrm{~cm}$. Sz: $5,8-6,7 \mathrm{~cm}$.

Hiányos szövőszéknehezékek, az átfúrásnál törtek el. M: 8,2 cm. Sz: 7-7,5 cm, M: $8 \mathrm{~cm}$. Sz: 7,5 cm és M: 7,7 cm. Sz: 7,1-8,3 cm.

Kisebb darabok, az átfúrásnál törek el, esetleg az előző szövőszéknehezékekhez tartoznak. H: 5,8 cm. Sz: $3,4 \mathrm{~cm}$ és $\mathrm{H}: 4,9 \mathrm{~cm}$. Sz: $4,5 \mathrm{~cm}$.

Szövőszéknehezék aljának töredéke. M: 6,6 cm. Sz: 6,9-7,8 cm.

\section{4. objektum}

Enyhén szűkülő falú, enyhén ívelt aljú gödör. Á: $120 \mathrm{~cm}$. Mé: $161 \mathrm{~cm}$. (VI. tábla).

14. objektum nyesése:

1. Oldaltöredék

Árkolt, ívelt, töredék. H: $6,9 \mathrm{~cm}$. Sz: $5 \mathrm{~cm}$. Fv: 0,7 cm. Ltsz: R.2000.6.1.

14. objektum, mé: $50 \mathrm{~cm}$ :

2. Megmunkált csonttöredék

Téglatest alakúra vágott csontlemez. $\mathrm{H}: 5,5 \mathrm{~cm}$. Sz: 2 cm. V: 0,3 cm. Ltsz: R.2000.6.2. (III. tábla. 10.)

14. objektum, mé: 0-100 cm:

3. Táltöredék

Kihajló peremü, a perem alatt belül árkolt. Sárga, vörös festéssel. Drag. 18/31. edény utánzata. H: 3,9 cm. Sz: $3,5 \mathrm{~cm}$. Fv: 0,5 cm. Ltsz: R.2000.6.3. (III. tábla. 6. $)^{9}$

4. Oldaltöredék

Enyhén ívelt, rádlimintás töredék. Porózus, sárga. $\mathrm{H}$ : 2,6 cm. Sz: 2,5 cm. Fv: 0,5 cm. Ltsz: R.2000.6.4.

5. Oldaltöredék

Enyhén ívelt, porózus, barna. $\mathrm{H}: 4,8 \mathrm{~cm}$. Sz: $3,1 \mathrm{~cm}$.

9 A lelőhelyen előkerült terra sigillata és utánzat meghatározását Horváth Friderikának ezúton is köszönöm.
Fv: 0,5 cm. Ltsz: R.2000.6.5.

6. Edény töredékei

Kihajló peremü, a váll éles töréssel csatlakozik, fekete. H: 6,1 cm. Sz: $5,4 \mathrm{~cm}$. Fv: 0,4 cm. (III. t. 8.). Az edényhez tartozó kisebb töredék: $\mathrm{H}: 3,2 \mathrm{~cm}$. Sz: 2,7 cm. Ltsz: R.2000.6.6.

7. Fazék töredékei

Kihajló, profilált peremű, Seprűs díszes fazék töredékei. Fekete, belül szürke. H: $8,7 \mathrm{~cm}$. Sz: 6,3 cm. Fv: $0,6 \mathrm{~cm}$. (III. t. 3.). Az edényhez tartozó kisebb töredékek H: 3,4 cm. Sz: $3 \mathrm{~cm}$. Fv: 0,5 cm. ill. H: 2,6 cm. Sz: 2,4 cm. Ltsz: R.2000.6.7.

8. Oldaltöredékek

Seprüs díszes töredékek, esetleg az előző edény darabjai. Átlagos fv: 0,5 cm- Ltsz: R.2000.6.8.

9. Edény töredékei

Kihajló peremü, a vállon árkolások futnak körbe. Simított, szürke. H: $7,3 \mathrm{~cm}$. Sz: 4,9 cm. Fv: 0,3 cm. Ltsz: R.2000.6.9. (III. tábla. 2.)

10. Edény töredékei

Nagyobb edény oldal- és aljtöredékei. Kaviccsal sűrün soványított, világosszürke. Átlagos Fv: $1 \mathrm{~cm}$. Ltsz: R.2000.6.10. (III. tábla. 4.)

11. Táltöredék

Kihajló peremű, csillámos felszínű, sötétszürke. H: 6,8 cm. Sz: 4,6 cm. Fv: 0,7 cm. Ltsz: R.2000.6.11. (III. tábla. 9.)

12. Peremtöredék

Kihajló, profilált peremü, sötétszürke. $\mathrm{H}: 4,1 \mathrm{~cm}$. Sz: $2,5 \mathrm{~cm}$. Fv: 0,5 cm. Ltsz: R.2000.6.12. (III. tábla. 1.)

13. Peremtöredékek

Különböző edények kihajló peremű, szürke színű töredékei. H: $3 \mathrm{~cm}$. Sz: 2,5 cm. Fv: 0,6 cm, ill. H: 2,7 cm. Sz: $1,8 \mathrm{~cm}$. Fv: 0,7 cm. Ltsz: R.2000.6.13.

14. Oldaltöredékek

Ívelt, finoman iszapolt, szürke színű töredékek, esetleg egy edény darabjai. Átlagos Fv: 0,6 cm. Ltsz: R.2000.6.14.

15. Fazéktöredék

Bordadíszes, ívelt, szürke színü töredék. $\mathrm{H}: 4,2 \mathrm{~cm}$.

Sz: 4,1 cm. Fv: 0,4 cm. Ltsz: R.2000.6.15.

16. Oldaltöredék

Ívelt válltöredék, kaviccsal soványított, szürke. H: 4,2 cm. Sz: 2,7 cm. Fv: 0,4 cm. Ltsz: R.2000.6.16.

17. Oldaltöredék

Ívelt válltöredék, kaviccsal soványított, szürke. H: 4,1 cm. Sz: 3,9 cm. Fv: 0,5 cm. Ltsz: R.2000.6.17.

18. Oldaltöredék

Árkolt, szürke színű oldaltöredék. H: $5,8 \mathrm{~cm}$. Sz: 3,1 cm. Fv: 0,6 cm. Ltsz: R.2000.6.19. (III. tábla. 5)

19. Oldaltöredék

Seprüs díszes, árkolt, fekete-barna színű töredék. H: 4 cm. Sz: 2,8 cm. Fv: 0,6 cm. Ltsz: R.2000.6.20.

20. Fazék töredékei

Részben seprüs díszes, fekete-barna színű töredékek, valószínűleg egy edény darabjai (9 db). Átlagos Fv: 0,8 cm. Ltsz: R.2000.6.21.

21. Oldaltöredék

Ívelt, jól korongozott, szürke. H: $6,5 \mathrm{~cm}$. Sz: 4,4 cm. Fv: 1 cm. Ltsz: R.2000.6.22. 
22. Aljtöredék

Jól korongozott, szürke. H: 5,6 cm. Sz: 4,4 cm. Fv: 0,9

cm. Ltsz: R.2000.6.23. (III. tábla. 7.)

23. Téglatöredék

Ujjbenyomásos töredék, barna-piros. H: $8,5 \mathrm{~cm}$. Sz:

$7,2 \mathrm{~cm}$. M: 0,9 cm. Ltsz: R.2000.6.24.

24. Fenőkő töredéke

Trapéz keresztmetszetü, szürke kvarc homokkő. H:

8,5 cm. Sz: 6,9 cm. M:3,4 cm. Ltsz: R.2000.6.25.

25. Patics

Áglenyomatos töredék, barna-piros. H: 7,2 cm. Sz: 6,5 cm. Ltsz: R.2000.6.26.

14. objektum, Mé: 100 cm-töl a gödör aljáig:

26. Patics

Áglenyomatos töredék, barna. $\mathrm{H}: 5,8 \mathrm{~cm}$. Sz: 4,1 cm.

Ltsz: R.2000.6.27.

27. Kőtöredék

Amorf töredék, szürke színü bazalttufa. $\mathrm{H}: 6,1 \mathrm{~cm}$. Sz: 5,4 cm. Ltsz: R.2000.6.28.

\section{5. objektum}

Téglalap alakú, lekerekített sarkú, csaknem négyzetes építmény ( $\mathrm{H}: 300 \mathrm{~cm}$. Sz: $270 \mathrm{~cm}$. VII. t.). A bányakitermelés során csaknem teljesen elpusztult, mélysége csak néhány $\mathrm{cm}$ volt. Az építmény alja egyenetlen, délnyugat felé lejt, sározásnak vagy döngölésnek nem volt nyoma. Az objektum négy sarkán és középen, a keleti és nyugati részen, egy-egy, összesen 6 cölöplyuka volt. Az összes cölöplyuk körül kisebb gödör volt, ami arra utal, hogy a cölöpöket kiásták. Ezt megerősíti az is, hogy több cölöplyukból került elő kerámiatöredék és megmunkált agancsdarab.

25. objektum, mélység: $120-150 \mathrm{~cm}$ :

1. Aljtöredék

Finoman iszapolt, szürke. H: $5,6 \mathrm{~cm}$. Sz: 4,4 cm. Fv: $0,8 \mathrm{~cm}$. Ltsz: R.2000.7.1. (III. tábla. 18)

2. Oldaltöredékek

Finoman iszapolt, simított, szürke színű töredékek (4 db). Átlagos Fv: 0,5 cm. Ltsz: R.2000.7.2.

3. Oldaltöredék

Enyhén ívelt, szürke. $\mathrm{H}: 2,2 \mathrm{~cm}$. Sz: 2,2 cm. Fv: 0,6. Ltsz: R.2000.7.2.

4. Kovadarab

Barna színű töredék. $\mathrm{H}: 1,8 \mathrm{~cm}$. Sz: $1,5 \mathrm{~cm}$. Ltsz: R.2000.7.3.

\section{Csiszolókő}

Egyik oldalán lesimított, szürke színű bazalttufa. H: 5,4 cm. Sz: 4,5 cm. Ltsz: R.2000.7.4.

6. Megmunkált agancsdarab

Két végén levágott, oldalt megfaragott agancsdarab. $\mathrm{H}$ :

3,9 cm. Á: 0,9-1,7 cm. Ltsz: R.2000.7.6. (III. tábla. 11.)

7. Megmunkált agancsdarab

Oldalain megfaragott agancsdarab. $\mathrm{H}: 3 \mathrm{~cm}$. Á: 1,9 cm. Ltsz: R.2000.7.7.

8. Megmunkált agancsdarab

Két végén levágott agancsdarabok ( $5 \mathrm{db})$. Átlagos Á: 3 cm. Ltsz: R.2000.7.8. (III. tábla. 11. és IV. tábla. 4-5.)

9. Megmunkált agancsdarab

Két végén levágott, oldalából egy szelet ki van vágva. Felső részén három koncentrikus kör alakú bevésés látható.
H: 9 cm. Á: 2,5 cm. Ltsz: R.2000.7.9. (III. tábla.17.).

10. Megmunkált agancsdarab

Egyik végükön lefürészelt agancsdarabok (3 db). Átlagos Á: 2,5 cm. Ltsz: R.2000.7.10. (IV tábla. 6.)

1 1. Megmunkált agancsdarab

Kisebb töredékek, egyik oldaluk lefürészelt (11 db). H:

3-6,8 cm. Ltsz: R.2000.7.11.

25. objektum, mélység: 150-160 cm:

12. Megmunkált agancsdarab

Egyik végén levágott, oldalt bevágott darab. $\mathrm{H}: 5,4 \mathrm{~cm}$.

Á: 2,9-1,7 cm. Ltsz: R.2000.7.12. (III. tábla. 12.)

13. Megmunkált agancsdarab

Három oldalán levágott csontlap. $\mathrm{H}: 2,9 \mathrm{~cm}$. Sz: $2 \mathrm{~cm}$. V: 0,3 cm. Ltsz: R.2000.7.13. (III. tábla. 16.)

14. Megmunkált agancsdarab

Két végén levágott agancsdarabok ( $5 \mathrm{db})$. Átlagos Á:

1,6. Ltsz: R.2000.7.14.

15. Megmunkált agancsdarab

Egyik végükön lefürészelt agancsdarabok (8 db). Átlagos Á: 1,9 cm. Ltsz: R.2000.7.15.

16. Megmunkált agancsdarab

Lefürészelt agancstő darabok (4 db). Átlagos Á: 5,7

cm. Ltsz: R.2000.7.16. (III. tábla. 14.)

17. Peremtöredék

Kihajló, barna színű peremtöredék. H: $5 \mathrm{~cm}$. Sz: 2,2 cm. Fv: 0,6 cm. Ltsz: R.2000.7.17. (III. tábla. 13.)

25. objektum alja:

18. Fazéktöredék

Seprüs díszes oldaltöredék, kaviccsal soványított, sötétszürke. H: 3,4 cm. Sz: $3,2 \mathrm{~cm}$. Fv: 0,4 cm. Ltsz: R.2000.7.18.

19. Oldaltöredékek

Finoman iszapolt, szürke színü, simított töredékek (4 $\mathrm{db}$ ), valószínüleg egy edény darabjai. Fv: 0,3 cm. Ltsz: R.2000.7.19. (III. tábla. 15.)

20. Oldaltöredékek

Simított, szürke színü töredékek (3 db). Fv: 0,5 cm. Ltsz: R.2000.7.20.

21. Oldaltöredékek

Különböző edények, szürke színü töredékei. Fv: 0,2 és

0,8 cm. Ltsz: R.2000.7.21-22.

22. Fenőkő töredéke

Félkör keresztmetszetü, szürke kvarc homokkö. H: 3,1 cm. SZ: 3 cm. M: 2,9 cm. Ltsz: R.2000.7.23. (III. tábla. 19.)

1. (nyugati cölöplyuk):

23. Patics

Barna színű töredék. H: $3,2 \mathrm{~cm}$. Sz. $2,5 \mathrm{~cm}$. Ltsz: R.2000.7.24.

24. Megmunkált agancsdarabok

Egyik, ill. mindkét végén lefürészelt agancsdarab. $\mathrm{H}: 4,6 \mathrm{~cm}$. Á: $1,8 \mathrm{~cm}$, ill. H: $5,8 \mathrm{~cm}$. Á: $2,1 \mathrm{~cm}$. Ltsz: R.2000.7.25. (III. tábla. 20.)

2. (keleti cölöplyuk):

25. Megmunkált agancsdarab

Végén levágott, oldalát négyzet keresztmetszetüvé formált agancsdarab. $\mathrm{H}: 6,1 \mathrm{~cm}$. Á: $1,8 \mathrm{~cm}$. Ltsz: R.2000.7.26. (IV. tábla. 2.)

26. Megmunkált agancsdarab

Két végén lefürészelt agancsdarab. $\mathrm{H}: 5,5 \mathrm{~cm}$. Á: 3,1 cm. Ltsz: R.2000.7.27. (IV. tábla. 1.) 
27. Oldaltöredék

Szürke színü, ívelt töredék. H: 2,8 cm. Sz: $2 \mathrm{~cm}$. Fv: 0,7 cm. Ltsz: R.2000.7.28.

5. (délkeleti cölöplyuk):

28. Megmunkált agancsdarab

Két végén levágott agancsdarab. H: $6,9 \mathrm{~cm}$. Á: $2,2 \mathrm{~cm}$. Ltsz: R.2000.7.29. (IV. tábla. 3.)

6. (északkeleti cölöplyuk):

29. Téglatöredék

Vörös színű töredék. $H: 7,1 \mathrm{~cm}$. Sz: $5,9 \mathrm{~cm}$. M: 2,3 cm. Ltsz: R.2000.7.30.

30. Oldaltöredék

Szürke színü, ívelt töredék. H: 2,4 cm. Sz: 1,7 cm. Fv: 0,8 cm. Ltsz: R.2000.7.31.

31. Megmunkált agancsdarabok Egyik végükön lefürészelt agancsdarabok (5 db). Átlagos Á: 0,6 cm. Ltsz: R.2000.7.32.

\section{6. objektum}

A bányamüvelés során csaknem teljesen elpusztult objektum. Felszínéröl, gyöngy mellett, égett tapasztásdarabok kerültek elö. Lehet, hogy egy kemence hamusgödre volt, vagy a gödör felszínén hosszan tartó tüzelés folyt, az erős pusztulás miatt már nem lehetett megállapítani. Az objektum fala meredek, alja teknős. H: $140 \mathrm{~cm}$. Sz: $100 \mathrm{~cm}$. Mé: $33 \mathrm{~cm}$. (VI. tábla.)

1. Gyöngy

Sárga szemes, sötétkék színű üveggyöngy. Á: $0,8 \mathrm{~cm}$. Ltsz: R.2000.8.1. (IV. tábla. 10. és 1. ábra.)

2. Fazék töredékei

Kihajló peremű, kézi korongon készült fazék töredékei. Barna, belül fekete. H: 12,4 cm. Sz: 8,9 cm. Fv: 0,7 cm. Ltsz: R.2000.8.2. (IV. tábla. 9.)

3. Fazék töredékei

Hasonló anyagú, barna színű töredékek (5 db), esetleg az előző edényhez tartoznak. Átlagos Fv: 0,7 cm. Ltsz: R.2000.8.3-4.

4. Fazék töredékei

Bordadíszes, szürke színű oldaltöredékek. $\mathrm{H}: 4,5 \mathrm{~cm}$. Sz: $4,2 \mathrm{~cm}$. Fv: 0,4 cm. (IV. tábla. 7.). A másik töredék H: 3,6 cm. Sz: 3,1 cm. Ltsz: R.2000.8.5.

5. Fazék töredékei

Különböző edények jól korongozott, szürke és bar-

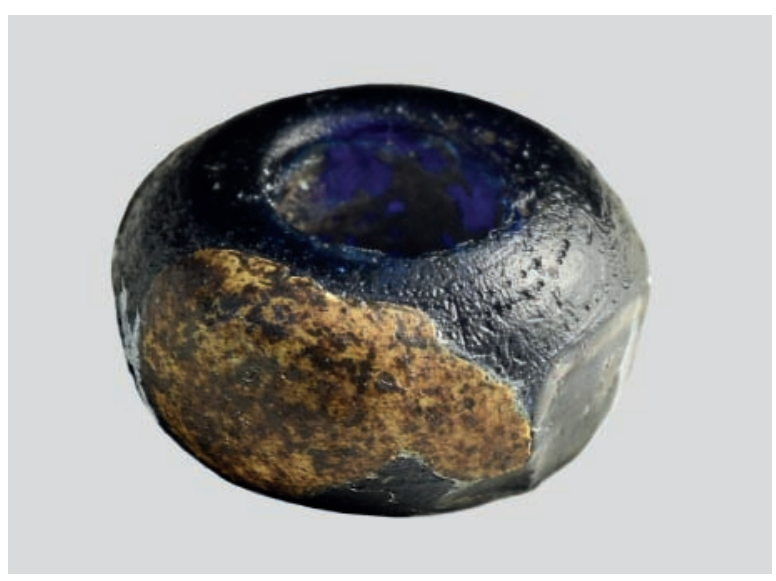

1. ábra. Gyöngy a 26. objektumból. na színü töredékei (3 db). Átlagos Fv: 0,7 cm. Ltsz: R.2000.8.6-7. (IV. tábla. 8.)

6. Patics

Barna színű töredék. H: $4,5 \mathrm{~cm}$. Sz: $2,8 \mathrm{~cm}$. Ltsz: R.2000.8.8.

\section{4. objektum}

Nagyjából kör alakú, meredek falú, teknős aljú gödör. Betöltése fekete, tetején átégett vörös réteg. Biztosan nem kemence volt, esetleg alkalmi tűzrakó hely lehetett. Á: $80 \mathrm{~cm}$. Mé: $22 \mathrm{~cm}$. (VI. tábla.)

1. Fazéktöredék

Jól korongozott, bordázott, szürke. H: 4,2 cm. Sz: 3,9 cm. Fv: 0,5 cm. Ltsz: R.2000.9.1.

2. Fazék töredékei

Kézi korongon készült, kaviccsal soványított fekete és barna színű töredékek, esetleg egy edény darabjai (11 db). Fv: 0,4 cm. Ltsz: R.2000.9.2.

3. Kőtöredék

Barna-szürke színü bazalttufa töredéke. $\mathrm{H}: 6,1 \mathrm{~cm}$. Sz: 3,8 cm. Ltsz: R.2000.9.3.

\section{8. objektum}

Ívelt oldalú tárológödör, betöltése fekete, alja nem került kibontásra. Á: $100 \mathrm{~cm}$. Mé: $100 \mathrm{~cm}$, a teljes mélysége kb. $160 \mathrm{~cm}$ lehetett. (VI. tábla.)

1. Edénytöredék

Kihajló peremü, a vállán ferde bevágások sorakoznak, szürke. H: 7,1 cm. Sz: 6,5 cm. Fv: 0,6 cm. Ltsz: R.2000.10.1. (IV. tábla. 12.)

2. Edénytöredékek

Jól korongozott szürke színű alj- és oldaltöredékek, egy edényhez tartoznak. Az oldaltöredék bordázott. $\mathrm{H}$ : 4,7 cm. Sz: 3,3 cm. Fv: 0,6 cm, ill. H: 5,9 cm. Sz: 4,4 cm. Fv: 0,8 cm. Ltsz: R.2000.10.2.

3. Oldaltöredék

Jól korongozott, szürke színü töredék. H: 4,2 cm. Sz: 2,2 cm. Fv: 0,4 cm. Ltsz: R.2000.10.3.

4. Fültöredék

Jól korongozott, árkolt, szürke színü töredék. H: 10,9 cm. Sz: 3,7 cm. Fv: 1,3 cm. Ltsz: R.2000.10.4.

5. Aljtöredékek

Nagyobb edények aljtöredékei. Jól korongozott, szürke színü töredékek. Tör M: 4,7 cm. Fv: $1,24 \mathrm{~cm}$, ill. Tör. M: 4,9 cm. Fv: 1,2 cm. Ltsz: R.2000.10.5. (IV. tábla. 11.)

6. Patics

Áglenyomatos, barna színü töredék. H. 7,8 cm. Sz: 4,9 cm. Ltsz: R.2000.10.6.

7. Csiszolókő töredéke

Egyik oldalán lecsiszolt vörös színű töredék. Anyaga kvarc homokkő, színe másodlagos égésre utal. H. 6,5 cm. Sz: 5,5 cm. Ltsz: R.2000.10.7.

\section{3. objektum}

Az objektum metszetét lehetett megfigyelni a bánya falában. A kitermelt földből állatcsont és patics mellett néhány római kerámiatöredék is előkerült.

1. Edénytöredék

Nagyobb edény éles töréssel csatlakozó váll- és hastöredéke. $A$ vállon besimított $X$ alakú minta fut kör- 
be. Szürke. H: 4,6 cm. Sz: 4,2 cm. Fv: 0,4 cm. Ltsz: R.2000.11.1. (IV. tábla. 15.)

2. Edénytöredék

Ívelt, összeillő töredékek, bordázott, barna. $\mathrm{H}: 3,7 \mathrm{~cm}$. Sz: 3,4 cm. Fv: 0,6 cm. Ltsz: R.2000.11.2 (IV. tábla. 14.)

3. Edénytöredékek

Különböző edények vékonyfalú, barna színű töredékei. H: 4,4 cm. Sz: 3,9 cm. Fv: 0,3 cm, ill. H: 4,5 cm. Sz: 2,9 cm. Fv: 0,4 cm. Ltsz: R.2000.11.3 (IV. tábla. 13.)

4. Edénytöredékek

Különböző edények szürke színű, részben sávos simítású töredékei. Átlagos Fv: 0,4 cm. Ltsz: R.2000.11.4

5. Patics

Barna, belül feketére égett töredék. H. 9,2 cm. Sz: 5,2 cm. Ltsz: R.2000.11.5

\section{Szórványleletek}

Szórványleletek az 1990. évi leletmentésből:

1. Terra sigillata edény töredéke

Figurális díszítésű edény piros színű töredéke. Drag. 37. edény töredéke, Rheinzaberni műhely. 18022o/230. között készült. H: 2,9 cm. Sz: 2,5 cm. Fv: 0,5 cm. Ltsz: R.2000.5.1. (IV. tábla. 19.)

2. Edénytöredék

Kihajló peremü, a vállon borda fut körbe, szürke. $\mathrm{H}$ : 5,7 cm. Sz: 4,1 cm. Fv: 0,4 cm. Ltsz: R.2000.5.2.

3. Fazéktöredék

Kihajló, profilált peremű, szürke színű, összeillő töredékek. H: $4,3 \mathrm{~cm}$. Sz: $3,4 \mathrm{~cm}$. Fv: $0,5 \mathrm{~cm}$. Ltsz: R.2000.5.3. (IV. tábla. 17.)

4. Oldaltöredék

Bordadíszes oldaltöredék, szürke. H: $5 \mathrm{~cm}$. Sz: 4,1 cm. Fv: 0,4 cm. Ltsz: R.2000.5.4. (IV. tábla. 16.)

5. Oldaltöredék

Ívelt, szürke színü töredék. H: $5,8 \mathrm{~cm}$. Sz: 2,4 cm. Fv: 0,4 cm. Ltsz: R.2000.5.5.

6. Oldaltöredék

Kézi korongon készült, kaviccsal sűrün soványított. Kívül barna, belül fekete. $\mathrm{H}: 4,5 \mathrm{~cm}$. Sz: $4,4 \mathrm{~cm}$. Fv: 0,6 cm. Ltsz: R.2000.5.6.

7. Oldaltöredékek

Különböző edények enyhén ívelt töredékei (4 db). Jól korongolt, szürke, ill. barna. Átlagos Fv: 0,7 cm. Ltsz: R.2000.5.7.

8. Megmunkált agancsdarab

Lefürészelt agancsdarab égésnyomokkal. H: $5,7 \mathrm{~cm}$. Sz: 3,1 cm. Ltsz: R.2000.5.10. (IV. tábla. 18.)

Szórványlelet az 1994. évi leletmentésböl:

9. Csontfésű töredékei.

A két töredékes szorítólemez mellett, a belső rész négy kisebb darabja maradt meg. A szorítólemezek szélei bevagdosottak, közepük árkolásokkal tagolt $X$ alakú, és rácsmintás véséssel díszített. A felerősítő vasszegek közül kettő maradt meg. A szorítólemezek $\mathrm{H}: 6,4$ és $5,1 \mathrm{~cm}, \mathrm{Sz}: 1,6 \mathrm{~cm}$. A belső rész Sz: $4,5 \mathrm{~cm}$. Ltsz: R.2000.12.1. (IV. tábla. 21.) $)^{10}$

10 Tóth József (Ordacsehi, Kossuth u. 41.) ajándékaként került be a kaposvári múzeumba. A bánya keleti részén került elő, leletmentés során objektumot nem lehetett megfigyelni. Tóth Józsefnek ezúton is köszönöm a lelet beadását

\section{Szórványlelet az 1995. évi leletmentésből:}

10. Bronzcsat.

Ép bronzcsat vaspecekkel, a csattest szélén két árkolással díszített, belül a felerősítő bronzszegecs is megmaradt. $\mathrm{H}: 1,8 \mathrm{~cm}$. Sz: $1,4 \mathrm{~cm}$. M: 0,5 cm. Ltsz: R.2000.13.1. (IV. tábla. 20. és 2. ábra.) ${ }^{11}$

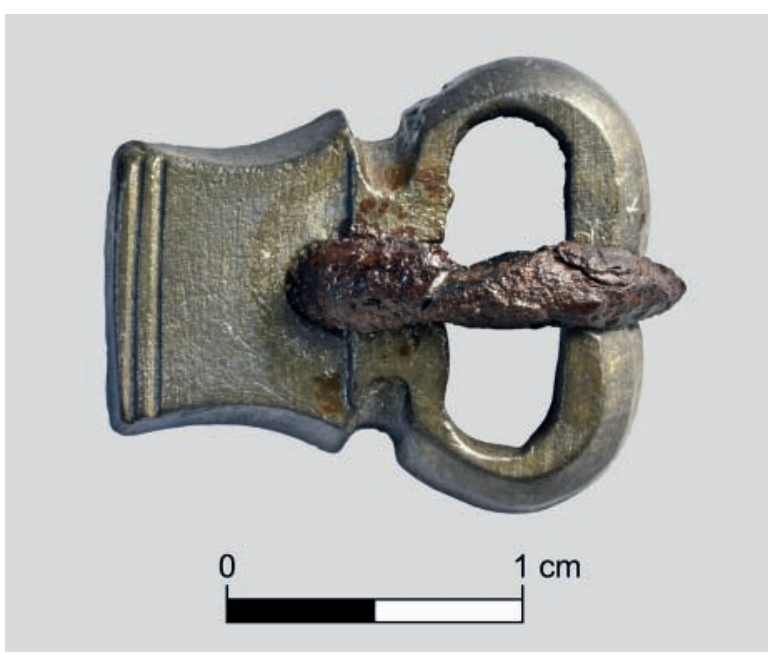

2. ábra. Szórvány bronzcsat.

\section{A leletanyag értékelése}

\section{Kerámia}

Az összesen nyolc objektumból, nagyon kevés leletanyag került elő. Ennek oka az, hogy a bányászás nagyon lepusztította a telepet. A leletanyag döntő része kerámiatöredék. Az előkerülési körülmények miatt ép, vagy kiegészíthető edény nem volt. Előfordult, hogy egy edénynek több darabja is megmaradt, több esetben a hasonló töredékek egy edényhez tartozhattak. A legtöbb kerámialelet apró oldaltöredék, melyet edénytípushoz nem lehet kötni. Az edénytöredékek sérültek, kopottak, a besimított darabokon a díszítés is erősen lekopott. Egy másodlagosan égett töredék került elő (1990/2. objektum 19. lelet), több töredék az egyenetlen kiégetés miatt foltos. A legtöbb darab házikerámia, néhány simított és besimított díszítéssel rendelkező töredék került még elő. Feltűnő, hogy egyetlen egy mázas töredéket sem találtak a leletmentések során. A házikerámián belül túlsúlyban vannak a keményre kiégetett, zömében szürke, sötétszürke színű töredékek. Néhány darab barna színű. Jellemző a kaviccsal való soványítás, több esetben erősen, túlzottan is. A legtöbb lelet díszítetlen, kevés darabon seprüzés, fésűsdísz, vagy gyengén kiemelkedő bordázás látható. Nagy százalékkal képviseltetik magukat a finoman iszapolt darabok, ezeknél feltűnően nagy számban találhatók olyan edények, melyeken hornyolt bordázás található. Kevés kézi korongon készült edény került elő, ezek mindegyike díszítetlen, de jó kidolgozásúnak mondhatóak. A felismerhető darabok nagy része fazekakhoz tartozó

11 1995-ben, a bánya északkeleti részén került elő, felszíni szórványként. 
töredék. A kisebb, nem meghatározható darabok nagy hányada, valószínüleg ehhez az edénytípushoz tartozott. Mind durvább kivitelben, mind finoman iszapolt anyaggal előfordulnak. Jellemző a hornyolt bordázás, ami a leányfalui típus jellemzője. ${ }^{12} \mathrm{~A}$ tovább élő díszítésmód legközelebb egy 5. század 2. felére keltezett Balatonszemes- Szemesi-berekben feltárt sírban fordul elö. ${ }^{13} \mathrm{~A}$ finoman iszapolt edények közül néhány darab esetleg már a következő típushoz, a kancsókhoz és korsókhoz is tartozhat. Ezek az edények a fazekak leletmennyiségéhez képest jóval kisebb arányban fordulnak elő. Kancsó vagy korsó vastag falú, kaviccsal durván soványított töredékei a 14. objektumból kerültek elő (III. tábla. 4.). Háromosztatú fültöredék a 38. gödör lelete, ugyanabban az objektumban talált kihajló, legömbölyített peremű, vállán ferde bevágásokkal díszített edénytöredék korsó vagy nagyméretű fazék töredéke lehetett. Egy kisebb töredéken a fül indulási helye maradt meg (I. tábla. 10.), az edényt hornyolt bordázással díszítették. Néhány töredék tálakhoz tartozott. Egy finoman kidolgozott, besimított díszü darabhoz (I. tábla. 6.) hasonló a leányfalui őrtoronyból ismert. ${ }^{14}$ Egy barna színű, vastag falú, S-profilú töredék párhuzamát ugyanott találjuk meg. ${ }^{15}$ Egy keményre kiégett, vállán bordadíszes töredék szórványként került elő. Megfelelőit megtaláljuk a pomázi villa leletei között. ${ }^{16}$ Előfordul a Keszthely-fenékpusztai erőd anyagában is. ${ }^{17} \mathrm{~A}$ kézi korongon készült edények közül egy nagyobb töredék az ordacsehi 26. objektumban volt (IV. tábla. 9.). Megfelelője a leányfalui anyagban fordult elő. ${ }^{18} \mathrm{Az}$ edényforma átmenetet képez a korsó és a fazék között. ${ }^{19}$ Több, kisebb töredék, mely az ordacsehi telep területén került elö (1990/1. objektum 14. és a 14. objektum 18. lelete), fazékhoz tartozhatott. Néhány töredéken besimított díszítés található. A 43. objektum edénydarabján besimított $X$ alakú díszítése rácsformát jelez (IV. tábla. 15.). Hasonló díszítése volt egy bikónikus táltöredéknek, mely nagyon kopott volta miatt rosszul kivehetö, ezért rajzon nem is jeleztük (I. tábla. 6.). Több, szintén lekopott simítású darab a csontfaragó mủhely aljáról került elő. A vékony- és vastag falú töredékek egy vagy két edényhez tartozhattak. Simított felületű edény több töredéke a 14. gödör leletei között volt (III. tábla. 2.). A feltűnően kevés számú, simított felületű és besimított darab a leányfalui őrtorony 370-420/430 közé keltezhető anyagával mutat hasonlóságot. ${ }^{20}$ Ordacsehiben két terra sigillata töredék került elő. Az egyik Drag 37. táltöredék, szórványlelet (IV. tábla. 19.). Rheinzaberni mühely terméke, 180-220/230 között készült. A másik darab (III. tábla. 6.) Drag. 18/31 edény utánzata, a 14. gödör anyagához tartozhatott. Ugyanebben az objektumban egy kisebb, rádlimintás, porózus, sárga

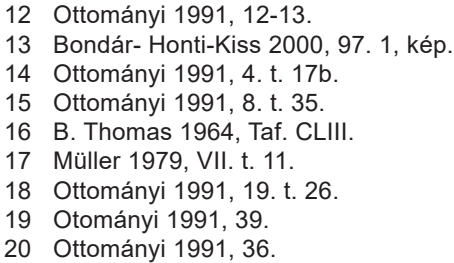

színű töredék is volt. A felsorolt edények nem tartoztak a késő római telep anyagához, a középső császárkor termékei.

Azordacsehi kerámialeleteklegjobban alimesmenti, késő római erődítmények anyagával rokoníthatók, Pilismarót-Malompatak, ${ }^{21}$ Pilisszántó-Kálvária, ${ }^{22}$ Leányfalu, ${ }^{23}$ Dunabogdány, ${ }^{24}$ és Visegrád-Gizellamajor ${ }^{25}$ anyaga mellett a tokodi ${ }^{26}$ és fenékpusztai ${ }^{27}$ erődök leleteit érdemes kiemelni. Távolabbi területek anyaga is nagy hasonlóságot mutat, pl. a Limberg-hedenstatti leletek. ${ }^{28} \mathrm{Az}$ értelemszerüen jóval szerényebb ordacsehi kerámialeletekből, mint már utaltunk rá, teljesen hiányoznak a mázas edények, a simított felületű és besimított díszítésü anyag is minimális. A mindennapi élethez szükséges fazekak és korsók, kancsók jelzik az ordacsehi mühely egykori tulajdonosának igényét. A kerámialeleteket néhány téglatöredék egészíti ki.

\section{Eszközök, viseleti tárgyak}

$A z$ ordacsehi objektumokból fémeszközök nem kerültek elő. Áttételesen mégis, a leletmentéseken megtalált fenőkövek, ezek meglétére utalnak. A három fenőkő (II. tábla. 5. és III. tábla. 19.) a lakógödörből és a műhelyben volt. Mindegyik sérült, erős kopottságuk hosszú használatra utal. Két kovakő is előkerült, ezek az őskori telepről is származhatnak, de a római kori használata is lehetséges. Az 1990//2. számú gödörházhoz tartozó megmunkált kődarab rendeltetése ismeretlen. Ugyanannak az objektumnak az alján heverő nehezékek feltehetően egyazon szövőszék részei lehettek. A nehezékek, méretük alapján, durvább szövet készítéséhez szolgáltak. ${ }^{29}$

A kécsimezői leletek egyetlen fémtárgya egy szórványként előkerült bronzcsat (IV. tábla. 20. és 2. ábra.). A kisméretű, díszített csattestű, de vaspeckes csat a római viseleti tárgyak közé tartozik. ${ }^{30}$ Gyakori melléklete a késő római temetőknek, pl. Somogyszil, 72. sír, ${ }^{31}$ és 144 . sír. ${ }^{32}$ A ságvári temetőben, az egyes előfordulások mellett, két sírból, párban is előkerült. ${ }^{33}$ Objektumból származik egy sárgaszemes, sötétkék színü üveggyöngy (IV. tábla. 10., 1. ábra.). ${ }^{34}$

Az objektumokból és szórványként előkerült csontfésűk (I. tábla. 1-2. és IV. tábla. 21.) a kétoldalas típusba tartoznak és a 4-5. századra egyaránt keltezhetők. ${ }^{35}$ Nem tudjuk, hogy a fésűk a helyi mühelyben készültek-e, ahol eleve több az agancstárgy, de a feltevés kézzelfoghatónak tünik. Az agancsok több ál-

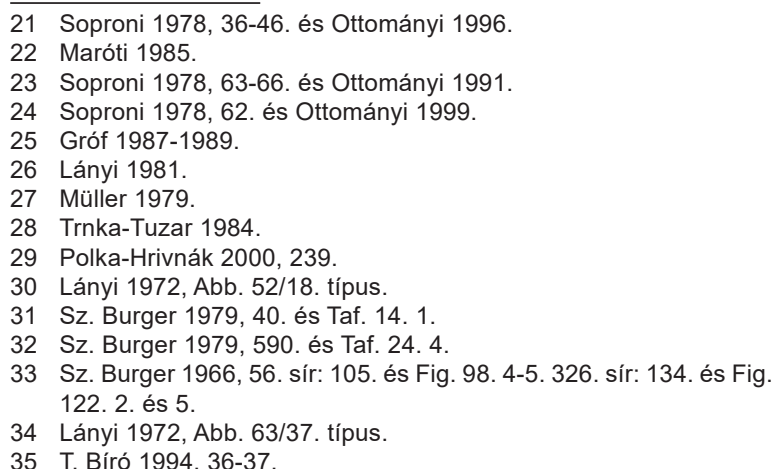


latfajtát is képviselhettek. ${ }^{36} \mathrm{Az}$ agancsokon több fázis megmunkálását lehet megfigyelni. ${ }^{37}$ Érdekes darab a 25/9. tárgy (III. tábla. 17.), melyen három koncentrikus kör alakú bevésés figyelhető meg. Hasonló tárgy, Bartus Dávid véleménye szerint, próbadarab lehetett. ${ }^{38}$ Csontmühely Intercisából ismert, ${ }^{39}$ a publikáló Salamon Ágnes szerint Pannoniában több előfordulásával is számolnunk kell. ${ }^{40}$ Ottományi Katalin, ezt elfogadva, több helyet is megjelöl a lehetséges műhelyek közül. ${ }^{41}$ Az előkerült leletek alapján, Brigetióban sikerült csontfaragó mühelyt lokalizálni. ${ }^{42}$
A leletek alapján a telep a 4 . század 3 . harmada és az 5. század első harmada közötti időszakban volt lakott. A település központi részén lévő csontfaragó mühely különlegessége az, hogy nem nagyobb településen, hanem a tartomány belsejében található. $A$ római kori telep teljes feldolgozása, melyben további csont- és agancstárgyak is találhatók, a mühely jelentőségét tovább fokozhatja.

\section{Irodalom}

BARTUS D. 2003: Adatok a brigetiói csontfaragó mühely lokalizáláshoz. - Komárom-Esztergom Megyei Önkormányzat Múzeumainak Közleményei 10: 55-75

T. BíRó M. 1994: The Bone Objects of the Roman Collection. - Catalogi Museio Nationalis Hungarici. Series Archaeologia II.

T. Bíró M. 2009: Historischer Überblick der Beinschnitzerwerkstätten in Intercisa. - Archaelogiai Értesítö 134: 63-79.

T. Bíró M., Choyke A. M., VAss L. És Vecsey Á. 2012: Aquincumi csonttárgyak. - Az Aquincumi Múzeum gyüjteménye 2.

BONDÁR M., HonTI Sz. És KIss V. 2000: A tervezett M7-es autópálya Somogy megyei szakaszának megelőző régészeti feltárása (1992-1999). Elözetes jelentés I. - Somogyi Múzeumok Közleményei 14: 93-114.

Sz. BuRger A. 1966: The Late Roman Cemetery at Ságvár. - Acta Archeologica XVIII: 99-234.

Sz. BURGER A. 1979: Der Spätrömische Gräberfeld von Somogyszil. Fontes Archaelogici Hungariae.

GRóF P. 1992: Népvándorlás kori vonatkozások egy késő római erőd és temető feltárásának kapcsán. - Józsa András Múzeum Évkönyve XXX-XXXII: 129-144.

LÁNYI V. 1972: Die spätantiken Gräberfelder in Pannonien. - Acta Archeologica XXIV: 53-213.

LÁNYI V. 1981: Die grue Spätrömische Keramik von Tokod. In: Die Spätrömiche Festung und Das Gräberfeld von Tokod. - Budapest 1981, 73-120.

MARÓTI É. 1985: Római őrtorony a pilsszántói Kálvárián. - Studia Comitatensia 17: 159-184.
MüLLER R. 1979: A Keszthely-fenékpusztai erőd északi kapujának feltárása 1971-ben. - Veszprém Megyei Múzeumok Közleményei 14: 123-156.

NÉmEth P. G., K. Zoffmann Zs. És BARTosiewicz L. 2002: Kelta temető és telep Ordacsehi határában. - Somogyi Múzeumok Közleményei 15: 57-74.

OTTOMÁNYI K. 1991: Késö római kerámia a leányfalui örtoronyból. Studia Comitatensia 22: 5-144.

OтTомÁNYI K. 1996: Eine Töpferwerkstatt der spätrömische Keramik mit Glättverzierung in Pilismarót-Malompatak. - Acta Archeologica XLIII: 71-133.

OTTOMÁNYI K. 1999: Late Roman Pottery in the Dunabogdány Camp. - Antaeus 24/1997-1998: 333-373.

OTTOMÁNYI K. 2001: „Hunkori” sírok a pátyi temetőben. - Archaelogiai Értesitö 126: 35-74

Polka M. ÉS HRIVNÁK P. P. 2000: A velemi Szent Vid szövőszéknehezék és orsógomb típusai. - Panniculus Ser. B. 5: 237-283.

SALAMON Á. 1976: Csontmühely Intercisában. - Archaelogiai Értesítő 103: $207-15$

SOPRONI S. 1978: Der Spätrömische Limes zwischen Esztergom und Szentendre. -Budapest 1978.

B. Thomas, E. 1964: Römische Villen in Pannonien. - Budapest 1964. TRINKA G. UND TUZAR J. 1984: Spätrömische/völkerwanderungzeitliche Siedlungsfunde von der Heidenstatt bei Limberg, Maissau, Niederösterreich. -Archaelogica Austriaca 68: 111-125.

VASS L. 2009: Beinschnitzerei in Intercisa. - Archaelogiai Értesítő 134: 81-90.

36 T. Bíró 1994, 36-37. T. Bíró M.-Choyke A. M.-Vass L.-Vecsey Á. 2012: Aquincumi csontárgyak. Az Aquincumi Múzeum gyűjteménye 2., 44-46.

37 Uo.29-31.

38 Bartus 2003, 63. Kat. 11. II. t. 5.

39 Salamon 1976., T. Bíró 2009. és Vass 2009

40 Salamon 1976, 208

41 Ottományi 2001, 54

42 Bartus 2003. 

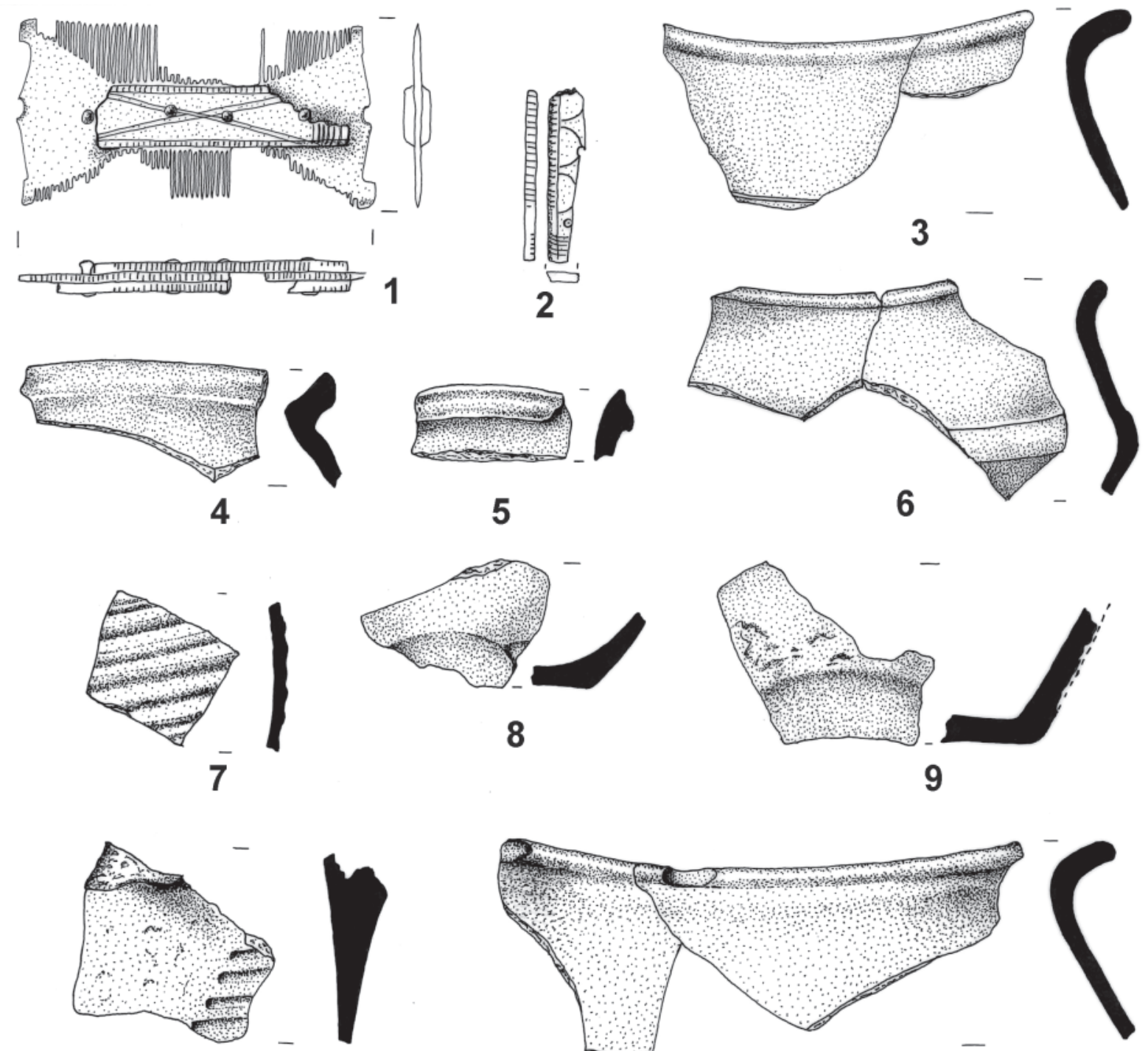

10
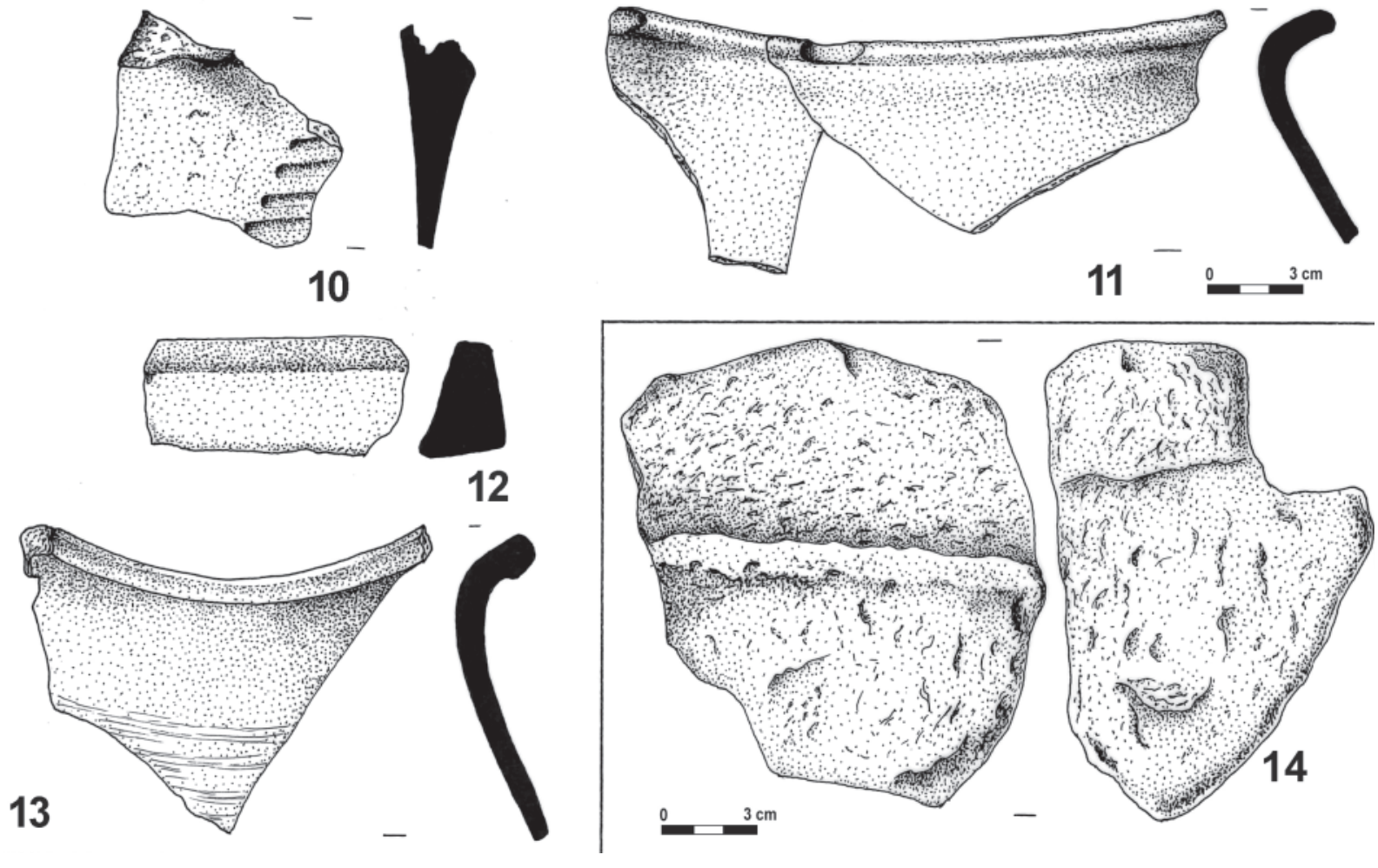

I. tábla: 1-13. 1990/1. objektum. 14. 1990/2. objektum. M: 1:2 

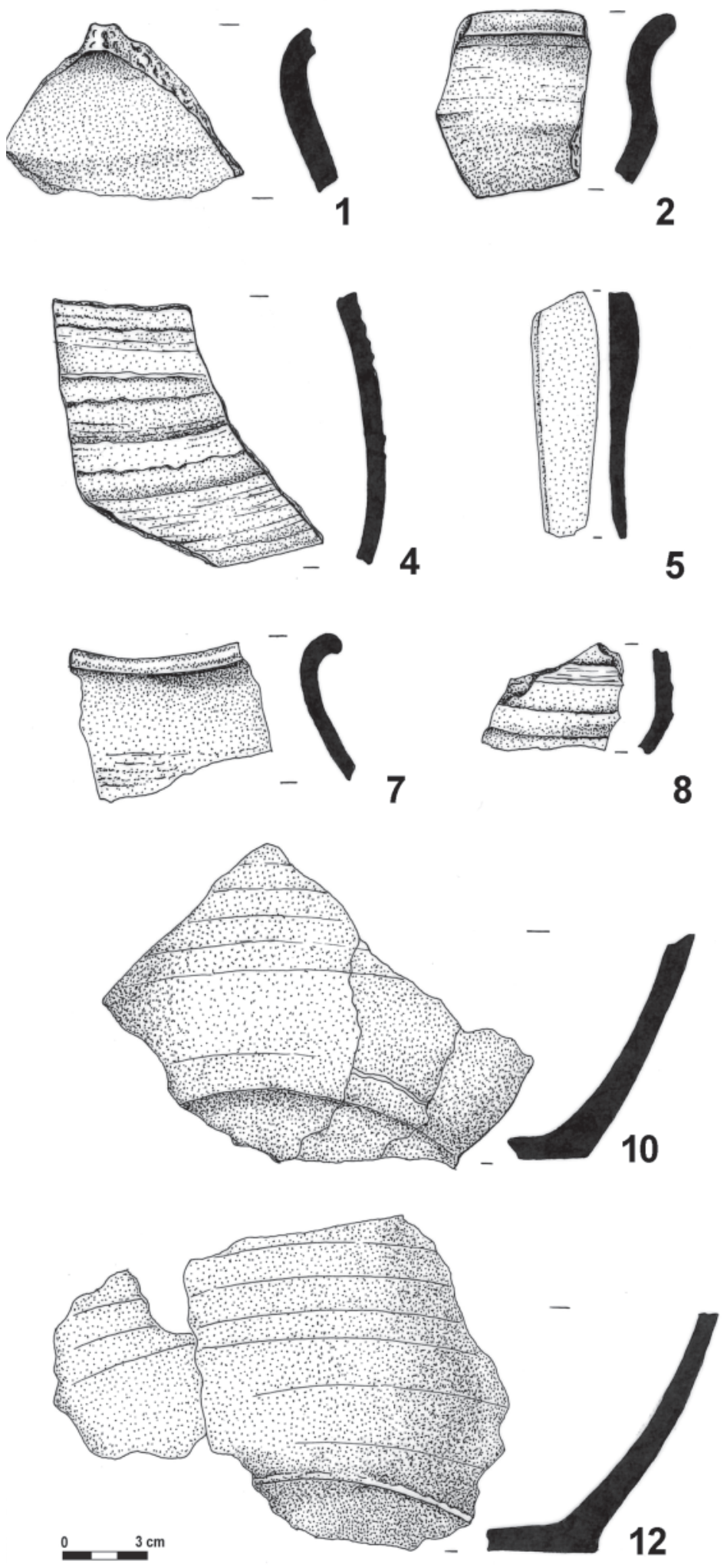

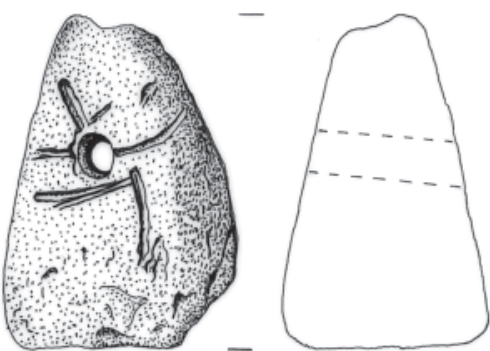

3
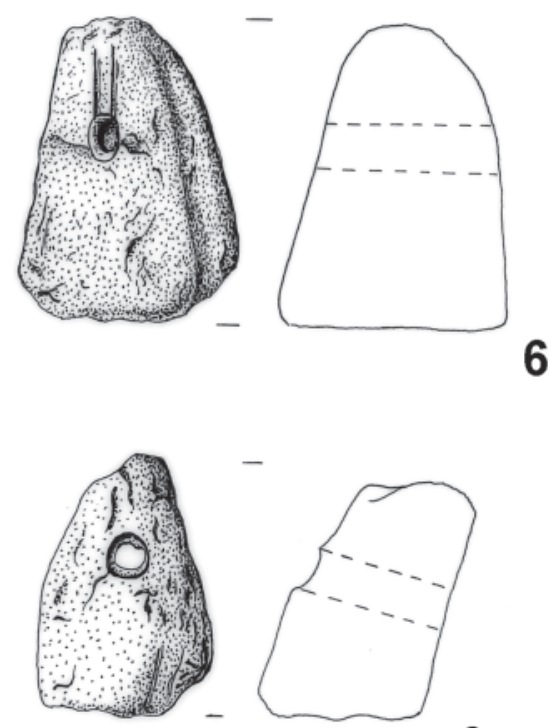

9

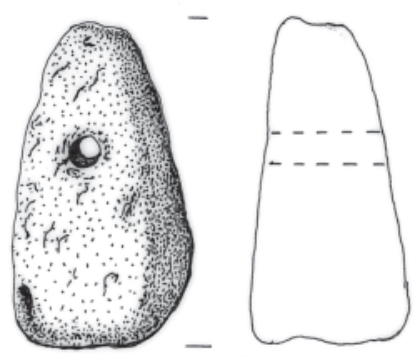

11

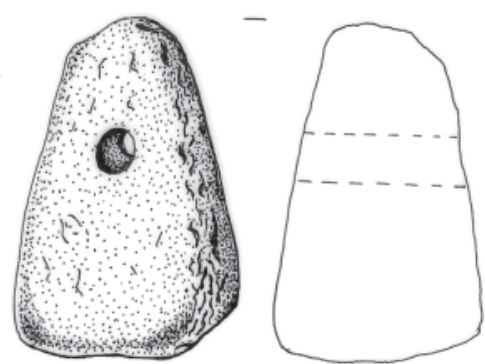

13

II. tábla: 1-13. 1990/2. objektum. 1-2., 4-5., 7-8., 10. és 12. M: 1:2. 3., 6., 9., 11. és 13. M:1:4 

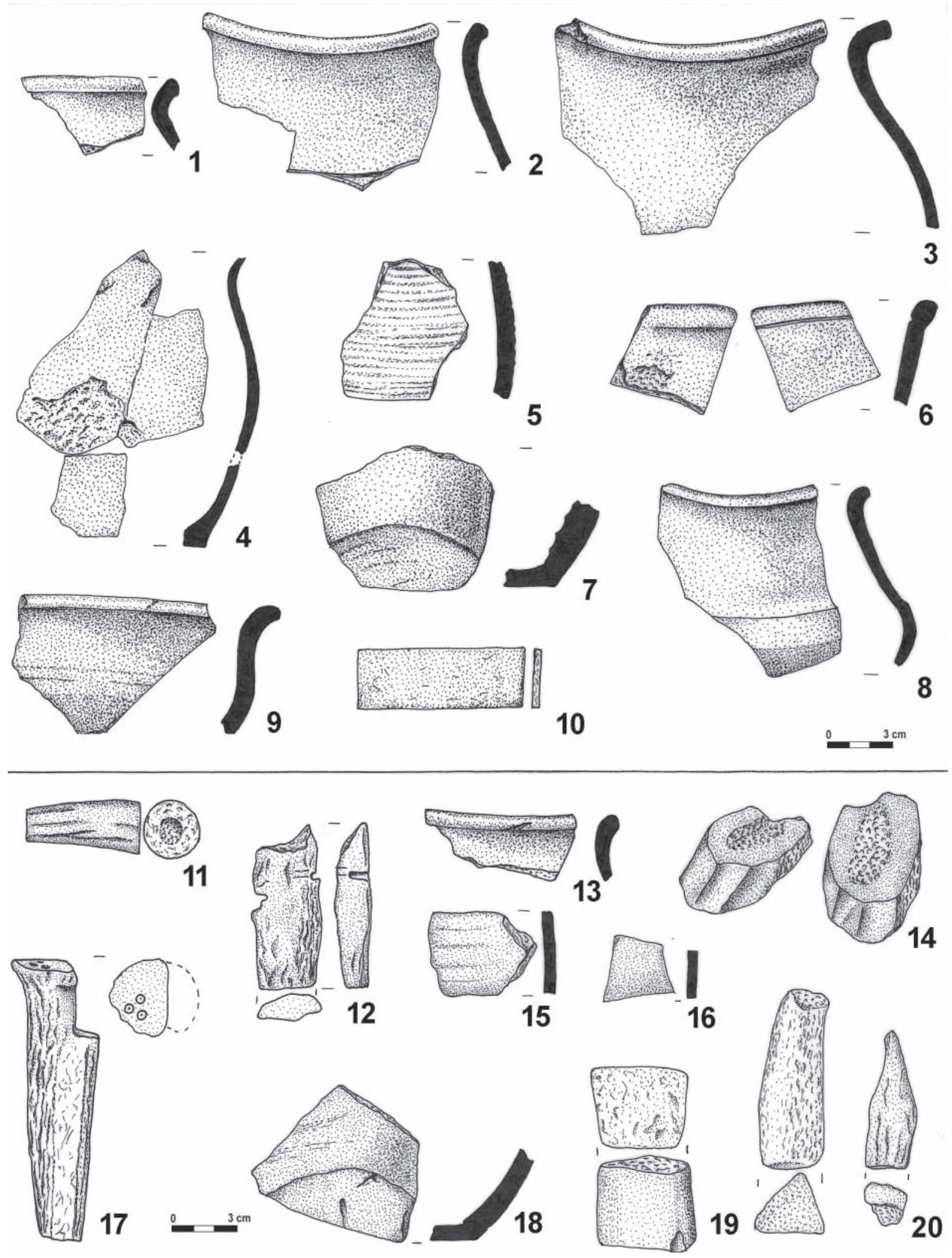

III. tábla: 1-10. 14. objektum. 11-20. 25. objektum. M:1:2 

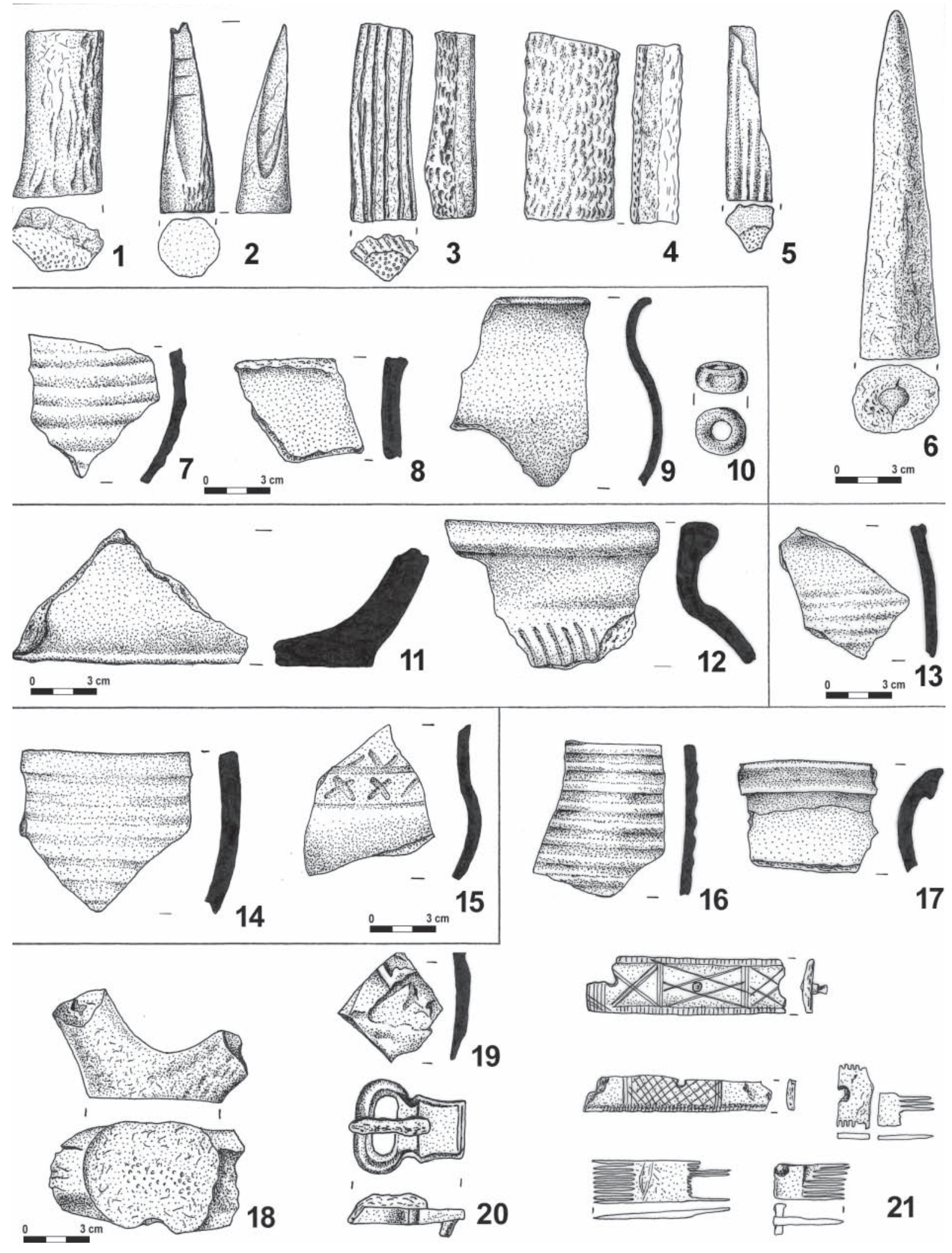

IV. tábla: 1-6. 25. objektum. 7-10. 26. objektum. 11-12. 38. objektum. 13-15. 43. objektum. 1-8., 11-19. és 21. M: 1:2. 9. M: 1:4. 10. és 20. M:1:1. 


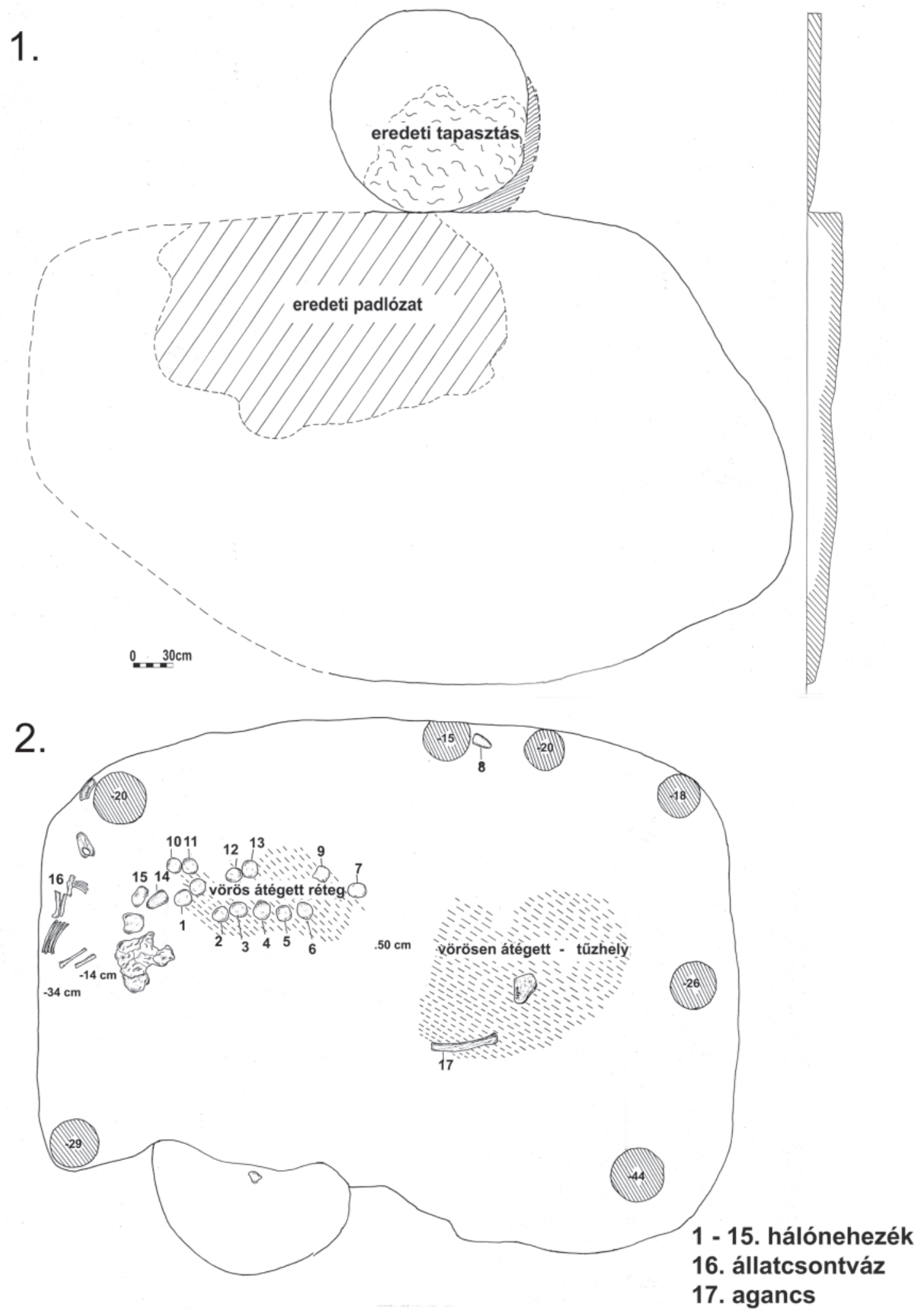

V. tábla: 1. 1990/1. objektum. 2. 1990/2. objektum 

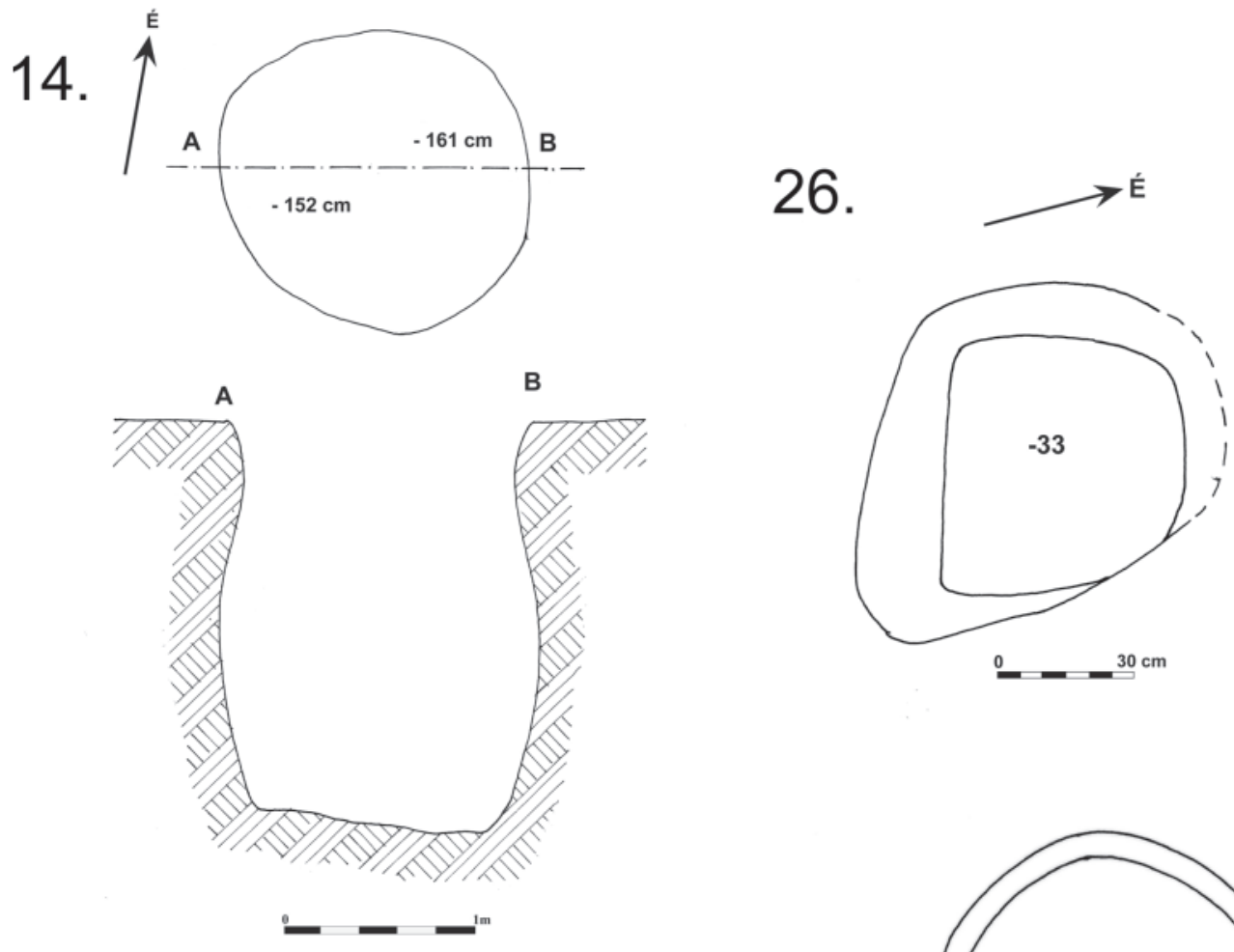

34.

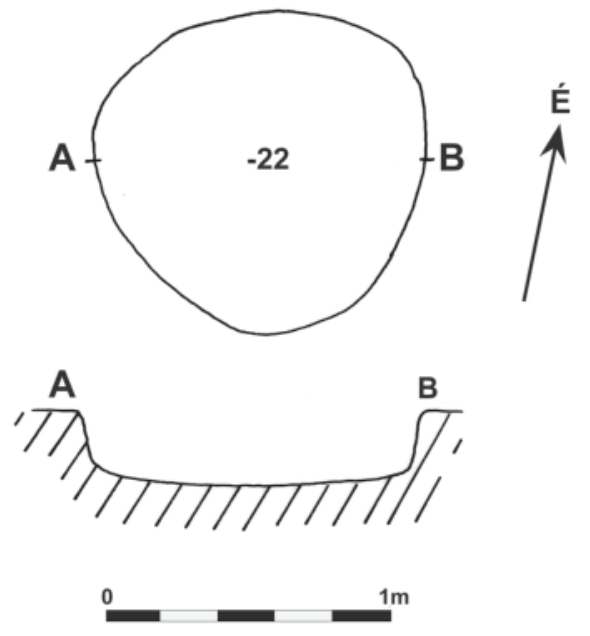

38.
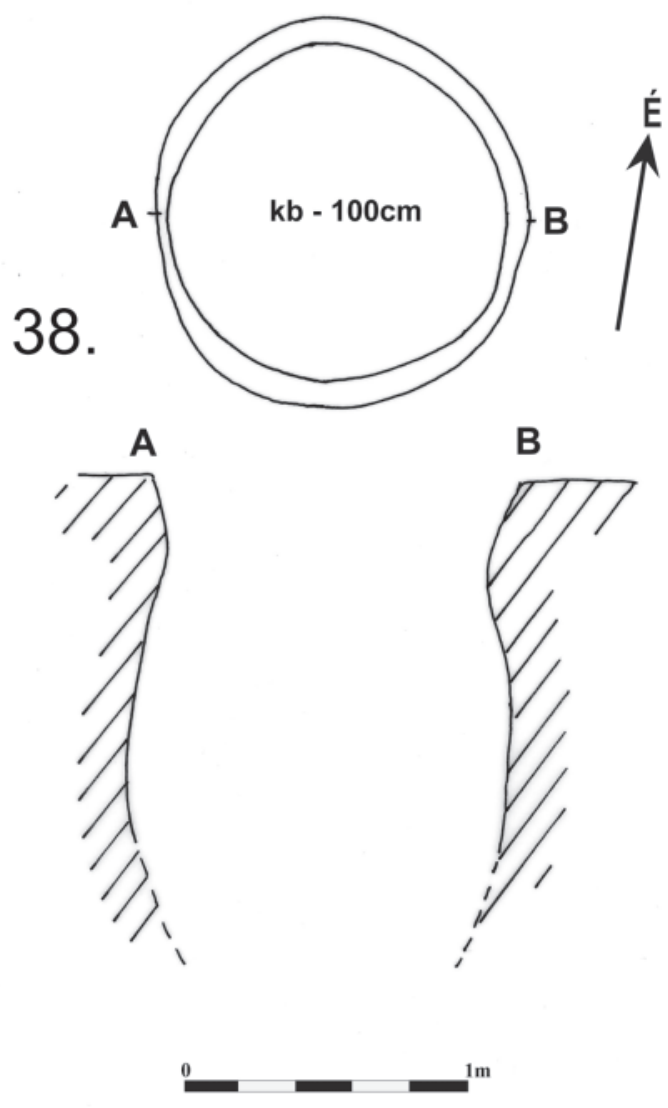

VI. tábla: 14., 26., 34. és 38. objektum 
25.

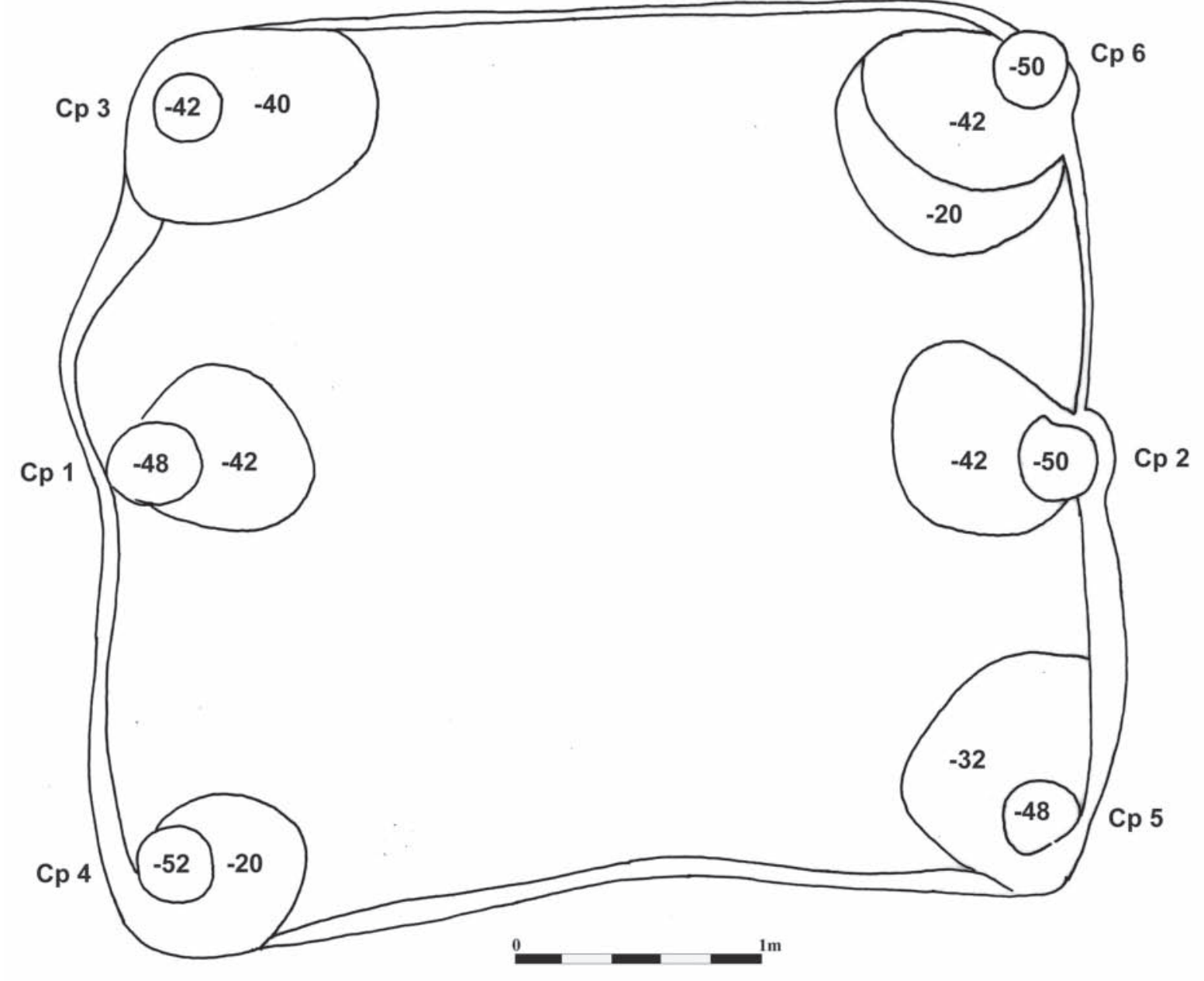


